\title{
PENERAPAN METODECOMPUTER AIDED INSTRUCTION (CAI) PADA APLIKASI PEMBELAJARAN TEMATIK BERBASIS MULTIMEDIA
}

\author{
Edizal Hatmi, Noferianto Sitompul, A.M. Hatuaon Sihite \\ Surel: hatmi1976@gmail.com
}

\begin{abstract}
Abstrak
Pemanfaatan komputer sebagai sarana pembelajaran dapat memberikan pengaruh yang sangat positif, perkembangan teknologi pembelajaran juga memiliki sifat yang interaktif. Para guru dapat menyulut minat anak-anak terhadap pembelajaran lewat penyertaan foto-foto, video, danaplikasi pembelajaran dalam bentuk slide misalnya menggunakan dengan Power Point.Disamping itu pula perlu adanya sebuah aplikasi tambahan berupa aplikasi pembelajaran berbasis multimedia yang dirancang menggunakan konsep metode CAI.Computer Aided Instruction (CAI) merupakan berbagai ragam informasi dalam cara pembelajaran. Komputer sebagai media akan lebih banyak membantu siswa menemukan hal-hal baru yang lebih menarik dibanding dengan cara-cara konvensional yang berpusat pada guru. Walaupun sudah diketahui bahwa cara-cara belajar dan mengajar, serta perolehan informasi pembelajaran tiap individu yang berbeda. Banyak teori-teori belajar yang berupaya menguraikan cara belajar tiap individu. Kebanyakan teori ini mengidentifikasikan menggunakan alat pelaga

komputer sebagai atribut-atribut pembelajaran.Uraian tentang pembelajaran tematik, ada orang yang belajar lebih suka dengan membaca, ada yang lebih baik mendengar, ada juga yang lebih suka belajar melalui perantara guru. Semua orang mempunyai tingkat berfikir yang berbedabeda yang mungkin memotivasi atau sebaliknya mendemotivasi cara belajar. Seseorang mungkin akan perlu berbantuan komputer untuk mengakses bahan-bahan pembelajaran supaya belajar menjadi menyenangkan dan tidak membosankan.
\end{abstract}

Kata Kunci: Multimedia, Tematik, Computer Aided Instruction (CAI)

\section{PENDAHULUAN}

Salah satu caramemudahkan penguasaan peserta didik terhadap kompetensi adalah penerapan teknologi dalam penggunaan media pembelajaran. Media pembelajaran sebenarnya merupakan alat atau media yang digunakan dalam membantu dan bertugas dalam suatu pembelajaran.Media pembelajaran membantu pemahaman belajar terhadap kompetensi yang harus dikuasai, dengan tujuan dapat mempertinggi hasil belajar.

Perkembangan teknologi informasi dan komunikasi berpengaruh terhadap perkembangan pembelajaran, dengan dikembangkan pembelajaran yang berbasis

PGSD FIP UNIMED

Manajemen Informatika Stmik Budi Darma Medan 
komputer.Komputermerupakan media yang menarik, atraktif dan interaktif.Pembelajaran melalui komputer memberikan bekal kepada peserta didik berbagai karakter yang menjadi kekuatan dan kelemahan suatu pembelajaran.

Proses belajar dapat dilakukan dengan banyak cara, baik itu melalui perantara guru, membaca buku atau pun secara otodidat. Pembelajaran pada awalnya dengan cara ceramah atau menjelaskan di depan kelas dari pendidik menggunakan bantuan peralatan papan tulis, kapur, gambar atau model. Pembelajaran memanfaatkan teknologi yang sederhana seperti Overhead Projector (OHP), slide, atau film. Dengan bantuan tersebut pendidik merasa terbantu dalam hal waktu, karena tidak perlu menulis dipapan tulis atau white board.Inti atau rangkuman materi pembelajaran OHP atau slide.Peserta didik dapat memanfaatkan waktu yang lebih banyak untuk berkomunikasi, diskusi ataupun bertanya langsung pada siswa lain atau guru yang mengajarnya. Namun proses belajar tersebut belum cukup untuk memenuhi keingintahuan. Karena pembelajaran oleh perantara guru terbatas waktunya dan kalau pembelajaran secara otodidak, belum tentu semua user hobi membaca buku dan harga buku yang terlalu mahal. oleh karena itu diperlukan cara yang cukup sempurna dalam implementasi.

Karena kelemahan tersebutlah dibutuhkan sebuah aplikasi pembelajaran berbasis multimedia menggunakan metode CAI yang nantinya membantu para guru dalam penyampaian materi pembelajaran tematik kepada peserta didik dalam hal ini siswa-siswi sekolah dasar.

Multimedia pembelajaran dapat diartikan menjadi sebagai sesuatu yang dapat digunakan untuk menyalurkan pesan (message), merangsang pikiran, perasaan, perhatian dan kemauan peserta didik sehingga dapat mendorong proses belajar. multimedia adalah kombinasi dari komputer dan video (Rosch, 1996) atau Multimedia secara umum merupakan kombinasi tiga elemen, yaitu suara, gambar dan teks (McCormick 1996) atau Multimedia adalah kombinasi dari paling sedikit dua media input atau output dari data, media dapat audio (suara, musik), animasi, video, teks, grafik dan gambar (Turban dkk, 2002) atau Multimedia merupakan alat yang dapat menciptakan presentasi yang dinamis dan interaktif yang mengkombinasikan teks, grafik, animasi, audio dan gambar video.

Computer aided instruction (CAI) menggunakan komputer sebagai satu bagian integral dari suatu sstem pembelajaran, para peserta didik pada umumnya terlibat dalam interaksi dua arah dengan computer melalui suatu terminal. CAI memberikan dampak terhadap bidang pendidikan.Dalam mengani jumlah besar yang berbagai ragam informasi tentang berbagai tipe dan jenis serta klasifikasi peserta didik, lembaga pendidikan membutuhkan kemampuan dalam bidang informasi.

Penelitian yang dilakukan (Wilhelm Wundt, 2001) tentang softwareeducation design instruction bahwa sebuah media pembelajaran dalam dunia pendidikan harus mempunyai umpan balik dan siswa harus dapat mengetahui seberapa jauh pemahaman yang diperoleh dari media pembelajaran tersebut, serta media pembelajaran ini harus menyenangkan, indah, dan pengguna tidak mudah bosan, maka untuk setiap media pembelajaran dengan komputer harus mengedepankan desain tampilan serta desain untuk materi. 
Pembelajaran tematik merupakan sebagai model pembelajaran memiliki arti penting dalam membangun kompetensi peserta didik. Pembelajaran tematik lebih menekankan pada keterlibatan siswa dalam proses pembelajaran, sehingga siswa dapat memperoleh pengalaman lansung dan terlatih untuk menenmukan sendiri berbagai pengetahuan yang dipelajari dan memahami konsep-konsep yang mereka pelajari dan menghubungkan dengan konsep lain yang telah dipahami.

Menurut (Robin dan Linda, 2001) multimedia adalah kombinasi dari komputer dan video (Rosch, 1996) atau Multimedia secara umum merupakan kombinasi tiga elemen, yaitu suara, gambar dan teks (McCormick 1996) atau Multimedia adalah kombinasi dari paling sedikit dua media input atau output dari data, media dapat audio (suara, musik), animasi, video, teks, grafik dan gambar (Turban dkk, 2002) atau Multimedia merupakan alat yang dapat menciptakan presentasi yang dinamis dan interaktif yang mengkombinasikan teks, grafik, animasi, audio dan gambar video.

Pembelajaran berbasis komputer (CAI) memiliki aspek-aspek yang dapat meningkatkan efektifitas pembelajaran.komputer dapat secara cepat berinteraksi dengan individu, menyimpan dan memproses berbagai informasi. Dalam menunjang pencapaian tujuan pembelajaran komputer yang disusun dengan program yang bermacam-macam tipe terminal dapat mengontrol interaksi belajar mandiri untuk mempelajari informasi yang disajikan.komputer dapat secara langsungdigunakan untuk menyampaikan materi pelajaran siswa, memberikan latihan dan memberikan tes kemajuan siswa (Hamalik, 2003).

CAI adalah salah satu metode pengajaran yang digunakan untuk membantu pengajar dalam mengajarkan materi secara interaktif dalam sebuah program tutorial dengan menggunakan suatu aplikasi komputer.Ada pun ciri-ciri sistem CAI yaitu:

Pelajar dapat mengakses materi ajar :

Tanpa dibatasi waktu

Tanpa dibatasi ruang dan tempat

Dukungan komunikasi

Sinkron

Asinkron

Dapat direkam

Jenis materi ajar

Multimedia (teks, gambar, audio, video dan animasi)

Paradigma pendidikan "Learning-Oeriented"

Asumsi : setiap pelajar ingin belajar dengan sebaik-baiknya

Pelajar akan secara aktif terlibat dalam membangun pengetahuan dn mengaitkannya dengan apa-apa yang telah diketahuinya atau dia alaminya.

Prinsip Pengembangan Program Computer Aided Instruction (CAI). Pada

prinsipnya langkah pertama dalam mengembangkan program CAI adalah menentukan metode apa yang akan digunakan penentuan metode ini tergantung dari jenis mata pelajaran itu sendiri, level kognitif yang akan dicapai, dan macam kegiatan belajar.

Metode CAI dibedakan menjadi lima jenis, yaitu : tutorial, latihan dan praktek, pemecahan masalah, simulasi, dan permainan (Budiarjo, 1991) 


\section{Tutorial}

Tutorial memakai teori dan strategi pembelajaran dengan memberikan materi, pertanyaan, contoh : latihan dan kuis agar murid dapat menyelesaikan suatu masalah, tujuannya adalah membuat siswa memahami suatu konsep/materi yang baku. Akan tetapi system ini disertai dengan modul remedial maka bila gagal, siswa akan diberikan remedia terhadap topic yang salah saja.

Latihan dan Praktek

latihan dan praktek merupakan metode pengajaran yang dilakukan dengan memberikan latihan yang berulang- ulang, tujuannya yaitu siswa akan lebih terampil, cepat, dan tepat dalam melakukan suatu keterampilan

Pemecahan masalah

Pemecahan masalah adalah suatu metode mengajar yang mana siswanya diberi soalsoal, lalu diminta pemecahannya, tujuannya menganalisis masalah dan memecahkan masalah tersebut.

Simulasi

Proses simulasi biasanya digunakan untuk mengajarkan proses atau konsep yang tidak secara mudah dapat dilihat (abstrak), seperti bagaimana bekerjanya suatu proses ekonomi, atau bagaimana hubungan antara supply and demand terhadap harga.

Permainan

Materi dari permainan merupakan hal yang ingin diajarkan, sekaligus juga berperan sebagai motivator. Pendekatan motivasi dapat dibedakan seperti motivasi intrinsic tidak ada reword diluar atau tanpa reword seperti "point" misalnya siswa menyenangi permainan tersebut.

\section{METODE PENELITIAN}

\section{Rancangan}

Sebelum merancang sebuah sistem, perlu dilakukan analisa terlebih dahulu terhadap permasalahan yang akan diselesaikan. Analisa perancangan adalah proses menentukan kebutuhan sistem, apa yang harus dilakukan sistem untuk memenuhi kebutuhan klien (user). Dengan adanya analisa perancangan, sistem yang dirancang akan lebih baik dan memudahkan pengembang sistem dalam perbaikan apabila pada kemudian hari ditemukan kesalahan atau kekurangan. Pada bab ini akan dijelaskan lebih lanjut tentang perancangan aplikasi media pembelajaran dan bagaimana menerapkan metode Computer Aided Instruction (CAI)dalam aplikasi media pembelajaran temamik.

Proses pembelajaran di lembaga pendidikan selalu dilakukan berdasarkan pada silabus kurikulum dan Rencana pelaksaan pembelajaran (RPP) yang telah disusun dan diatur pada setiap jadwal pelaksanannya. Silabus sebagai sebuah rencana pembelajaran pada suatu kelompok mata pelajaran/tema tertentu yang telah mencakup standar kompotensi, kompotensi dasar, materi pokok pembelajaran, kegiatan pembelajaran, indikator pencapaian kompotensi untuk penilaian, penilaian, alokasi waktu dan sumber belajar.merupakan perkiraan atau proyeksi mengenai tindakan apa yang akan dilakukan pada saat melaksanakan kegiatan pembelajaran. RPP menggambarkan prosedur dan pengorganisasian pembelajaran untuk mencapai satu kompotensi dasar yang diterapkan dalam standar isi dan telah dijabarkan dalam silabus. 
Pelaksaan proses pembelajaran tematik kelas 3 SD yang merupakan salah satu mata pelajaran pokok yang termasuk dalam rumpun perhitungan dan juga mengikuti pokok-pokok materi yang telah disusun dalam silabus kurikulum pembelajaran tematik. Materi-materi pokok pembelajaran khususnya mata pelajaran tematik telah disusun sedemikian rupa serta disesuaikan dengan alokasi waktu yang dibutuhkan selama pelaksanaan pengajaran dalam semester berjalan.

Keterbatasan alokasi waktu, sumber pembelajaran, dan jarak dalam proses pembelajaran menimbulkan kurang efektifnya proses pembelajaran yang sudah ada, dimana waktu pembelajaran disekolah yang terbatas, dan keterbatasan jarak yang membatasi peserta didik untuk belajar lebih, kerena telah terjadwalnya proses belajar mengajar disekolah sehingga tercapainya kompotensi dasar sesuai yang telah diterapkan di dalam silabus kurikulum tidak didapatkan. Oleh karena keterbatasan tersebut, maka pembelajaran yang sudah ada disekolah harus ditambah dengan pembelajaran berbantuan kompuetr dengan menggunakan computer aided instruction (CAI).

Perancangan aplikasi yang akan dibangun merupakan perangkat lunak media pembelajaran tematik yang mempu memberikan pembelajaran materi-materi tentang tematik pada tahap analisa dilakukan materi pembelajaran khususnya materi tematik. Hasil dari analisa digunakan sebagai acuan dalam menyusun spesifikasi yang diperlukan dalam aplikasi pembelajaran tematik.

\section{HASIL PENELITIAN DAN PEMBAHASAN}

Hasil yang diharapkan dalam penerapan metode CAI dalam pembuatan aplikasi pembelajaran berbasis multimedia berupa tahapan menu aplikasi seperti :

\section{Tutorial}

Bagian totarial dalam aplikasi media pembelajaran ini menyajikan materi-materi yang merupakan kumpulan topik-topik tematik.Pada program ini memberi kesempatan untuk menambah materi pelajaran yang telah dipelajari atau pun yang belum dipelajari sesuai dengan kurikulum yang ada.Tutorial memberikan layar bantuan untuk memberikan keterangan tentang media pembelajaran. Tutorial memakai teori dan trategi mempelajaran dengan memberikan materi, agar siswa dapat menyelesaikan suatu masalah dan memahami suatu konsep atau materi yang baku.

Model tutorial adalah salah satu jenis metode pembelajaran yang memuat penjelasan, rumus, prinsip, bagan, tabel, defenisi istilah, dan latihan yang sesuai.Dalam interaksi tutorial ini informasi yang disajikan sangat komunikatif, seakan-akan ada tutor yang mendampingi siswa dan memberikan arahan secara lansung pada siswa. Sehingga model tutorial sangat efektif untuk membantu siswa dalam proses belajar mengajar pada mata pelajaran elektonika. Maka untuk mengembangkan model tutorial ini kedalam pembelajaran tematik dibutuhkan soal-soal latihan.Soal-soal latihan bertujuan untuk membantu siswa memperdalam penguasaan tentang isi pembelajaran disamping untuk mengatahui sejauh mana tujuan khusus pembelajaran yang telah dicapai.Soal-soal latihan ini disertai umpan balek yang dapat memberikan penilaian langsung pada kemampuan siswa diserta penjelasan perlunya dilakukan pengulangan kembali terhadap materi yang dipelajari.

Sasaran dari model tutorial adalah dapat mengatur kecepatan persentasi sesuai dengan kebutuhan belajar siswa.Dengan menggunakan teknik percabangan dan interaktif, 
CAI tutorial dapat memberikan intruksi tambahan bagi siswa yang membutuhkannya dan memperkenankan setiap siswa untuk dapat menyelesaiakan pembelajaran materi ajar dengan cepat.

Adapun langkah-langkah dalam model tutorial adalah sebagai berikut :

Pengenalan (introduction) yaitu pengenalan terhadap aplikasi tersebut

Penyajian informasi (presentation of information) yaitu penyajian informasi bagi pengguna dalam bentuk materi pembelajaran menggunakan aplikasi tersebut Pertanyaan dan respon (question and responses) yaitu memberi pertanyaan kemudian aplikasi memberi respon yang berbentuk keterangan dan penilaian (scorring)

Penilaian respon (judging reponses) yaitu memberi penilaian (scorring)

Pemberian feedback tentang respon (providing feedback about reponses), setelah pengguna mendapat keterangan atas hasil yang diproleh dalam menjawab pertanyaan dan respon yang diberi maka aplikasi memberi feedback dalam bentuk saran untuk pengguna

Pembetulan (remedation) yaitu pembetulan dapat dilakukan setalah pengguna pembuka kunci jawaban

Penutup (clossing) artinya aplikasi selesai di jalankan

Adapun contoh tutorial dalam aplikasi pembelajaran ini adalah diuraikan sebagai berikut :

Materi tentang cara menghitung untuk anak didik kelas 3 SD.

Kolam ujang terletak dibelekang rumah, kolam ujang berbentuk persegi panjang.

Kolam itu diberi nama kolam ABCD.

Panjang $\mathrm{AB}$ sama dengan panjang $\mathrm{CD}$.

Panjang $\mathrm{AB}=6$ meter.

Jadi, panjang $\mathrm{CD}=6$ meter.

Lebar BC sama dengan lebar AD.

Lebar $\mathrm{BC}=4$ meter

Jadi lebar $\mathrm{AD}=4$ meter

Ujang ingin menghitung keliling kolam.

Keliling kolam ABCD adalah jumlah dari keempat sisi-sisinya.

Keliling persegi panjang $\mathrm{ABCD}=$ panjang $\mathrm{AB}+$ panjang $\mathrm{BC}+$ panjang $\mathrm{CD}+$ panjang $\mathrm{AD}$

$6+4+6+4$

$20 \mathrm{~m}$

Keliling persegi panjang $=(2 \mathrm{x}$ sisi panjang $)+(2 \mathrm{x}$ sisi lebar $)$

( 2 x panjang + lebar $)$ 
Keliling persegi panjang $=2 \mathrm{x}($ panjang + lebar $)$

Luas persegi panjang $=$ panjang $\mathrm{x}$ lebar

Pembelajaran tematik terbagi menjadi 4 mata pelajaran seperti Bahasa Indonesia, IPS, PKN, dan Matematika yaitu sebagai berikut :

a. Pelajaran Bahasa Indonesia

Memahami teks dengan membaca nyaring, membaca intensif, dengan membaca hasil diskusi di depan kelas secara bergantian.

Mengungkapkan pikiran, perasaan, pengalaman, dan petunjuk dengan bercerita dan memberikan tanggapan/saran.

1.1 Membaca nyaring dengan intonasi dan lafal yang tepat.

Pelajaran PKN

Negara kesatuan Republik Indonesia sangat besar dan luas.Negara kita terdiri atas ribuan pulau.Penduduk yang tersebar di berbagai pulau sangat beragam.Keragaman itu meliputi adat istadat, agama, maupun bangsa.Namun berkat semboyan Bhinneka Tunggal Ika, yang artinya berbeda-beda tetapi tetep satu jua, bangsa Indonesia menjadi bangsa yang besar.

Indonesia juga memiliki kekayaan alam yang sangat banyak.Dengan bentangan laut yang sangat luas, Indonesia kaya dengan sumber daya hutan, perkebunan, dan perternakan.

Salah satu kebanggaan bangsa Indonesia adalah bangsa Indonesia terkenal dengan keramahtamahannya. Keramahtamahan tersebut dapat dilihat pada poenduduknya yang selalu menghargai dan menghormati adat istiadat suku atau bangsa lain.

Pelajaran Matematika

Keliling persegi panjang $=2(\mathrm{p}+\mathrm{l})$

Luas persegi panjang $=\mathrm{p} \times 1$

Keliling persegi $=4 \mathrm{x}$ sisi

Luas persegi $=$ sisi $\mathrm{x}$ sisi 


\section{Latihan Dan Praktek}

Latihan dan praktek merupakan metode pengajaran yang dilakukan dengan memberikan latihan, tujuannya yaitu siswa akan lebih terampil, cepat, dan tepat dalam melakukan suatu keterampilan. Adapun tahapan dalam model latihan dan praktek adalah sebagai berikut :

Penyajian masalah-masalah dalam bentuk latihan soal-soal pada tingkat tertentu penampilan siswa. Soal-soal yang disajikan adalah soal-soal yang berhubungan yang telah dipelajari pada materi sebelumya.

Siswa pengerjakan soal-soal latihan

Program merekam atau menyimpan hasil jawaban siswa, mengevaluasi kemudian memberi umpan balik

Jika jawaban yang diberikan siswa benar, program akan menyajikan materi selanjutnya, dan jika jawaban siswa salah program menyediakan fasilitas untuk mengukangi latihan atau remediation, yang dapat diberikann secara parsial atau pada akhir keseluruhan soal.

Contoh isi dari latihan dan parktek adalah :

Pilihan ganda

Setrika mengubah energy listrik menjadi energy...

Gerak

Panas

Cahaya

Bunyi

Gambar bangun datar disamping disebut ....

Persegi

Persegi panjang

Segitiga

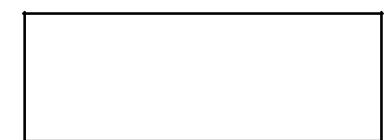

Lingkaran

Kebhineka bangsa Indonesia merupakan anugrah dari ...

Orang tua

Pemerintah

Masyarakat

Tuhan Yang Maha Esa

\section{Pembahasan}

Computer aided instruction (CAI) adalah salah satu metode pengajaran yang digunakan untuk membantu pengajar dalam mengajarkan materi secara interaktif dalam aplikasi komputer. Pemakai dapat berinteraksi melalui alat-alat input, seperti keyboard atau penekanan tombol dengan menggunakan mouse, yang hasilnya dapat ditampilkan melalui layar monitor dan printer. Metode CAI dibedakan menjadi lima jenis, yaitu tutorial, latihan, pemecahan masalah, video dan permainan mengenai tematik dengan tujuan agar dapat menambah pemahaman para siswa tentang materi yang dipelajari. 
Tutorial

Tutorial yang ditawarkan dalam perancangan aplikasi pembelajaran tematik dengan topik tematik berupa langkah-langkah dalam proses penjelasan secara teoritis tentang tematik.

Praktek dan latihan (drill and practice)

Praktek yang ditawarkan aplikasi pembelajaran tematik berupa penyelesaian latihanlatihan berupa soal-soal yang dapat diselesaikan langsung maupun melihat contoh penyelesaian yang disajikan (pemecahan masalah). Setelah mengerjakan soal, user dapat menginputkan jawaban yang kemudian akan di koreksi oleh sistem dan memberikan informasi kebenaran jawaban dan nilai para siswa.

Pemecahan masalah (problem solving)

Pemecahan masalah yang ditawarkan dalam aplikasi pembelajaran tematik berupa materi-materi soal tambahan yang memudahkan para siswa untuk lebih memahami jawaban yang diharapkan tentang materi-materi yang berhubungan dengan tematik.

Video

Permainan

Aplikasi media pembelajaran tematik dirancang menggunakan dengan aplikasi Macromedia Flash 8.0, dimana untuk merancang arsitektur interface dan mengetik listing program dilakukan pada interface Macromedia Flash 8.0 dan action script software tersebut.Aplikasi media pembelajaran tematik yang dirancang dengan menerapkan metode Computer Aided Instruction (CAI) pada penyampaian materi mengajar, dimana dengan metode ini peserta didik diharapkan dapat melakukan intraksi yang lebih interaktif dengan aplikasi yang dibangun.Berikut hasil dari implementasi program keseluruhan yang telah dirancang.

\section{Tampilan Menu Utama}

Frame yang pertama ditampilkan ketika aplikasi dijalankan adalah frame menu utama, dimana didalam frame ini akan disajikan beberapa menu pilihan yang dapat diakses oleh para pengguna. Menu pilihan yang disediakan adalah Menu Tutorial, Menu Latihan, Menu Pemecahan Masalah, Menu Vidio, Menu permainan dan Menu Keluar. Tampilan frame menu utama dapat dilihat pada gambar 1.dibawah ini.

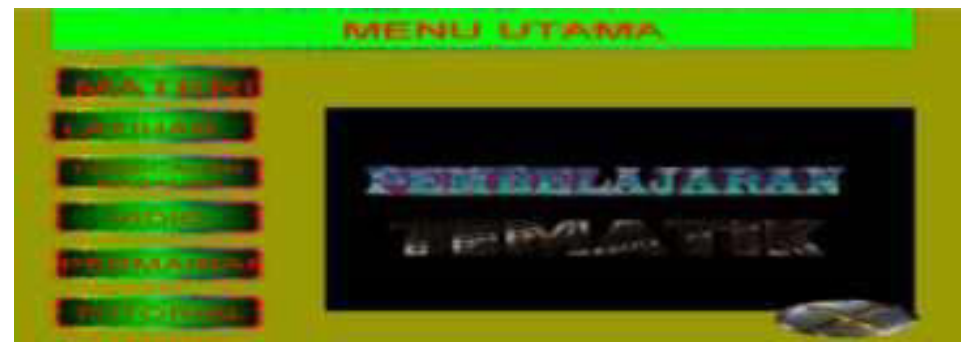

VIDEO Gambar Tampilan menu utama

\section{Menu Latihan}

Pada menu latihan ini menampilkan soal materi pembelajaran tematik, jika pada frame menu latihan user memilih pilihan ganda maka frame yang akn ditampilkan sebagai berikut. Menu pilihan ganda dapat dilihat pada gambar dibawah ini. 


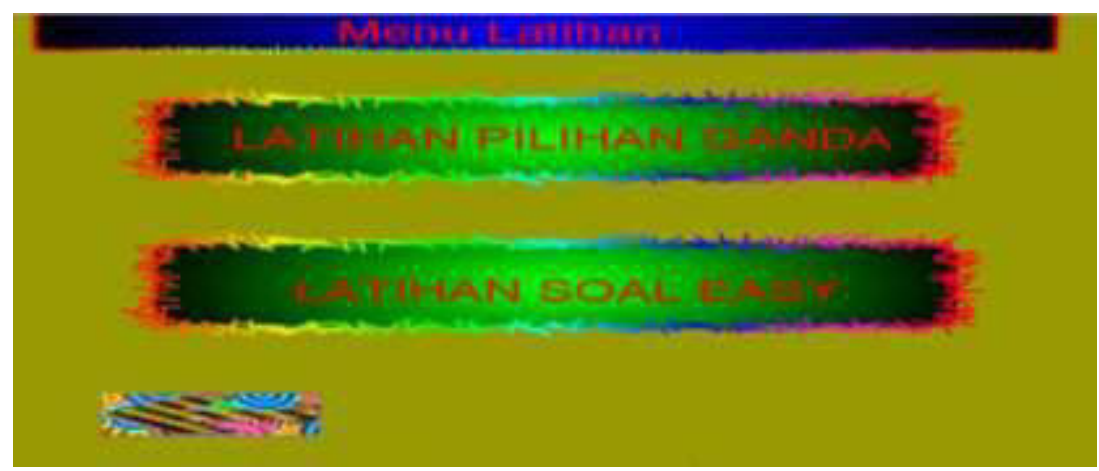

Gambar Menu latihan

Setelah mengklik menu latihan pilihan ganda, maka akan muncul sejumlah soal dalam media pembelajaran ini, dan soal latihan pilihan ganda menggunakan waktu otomatik, maka aplikasi akan menampilkan nilai seperti gambar 3.dibawah ini.

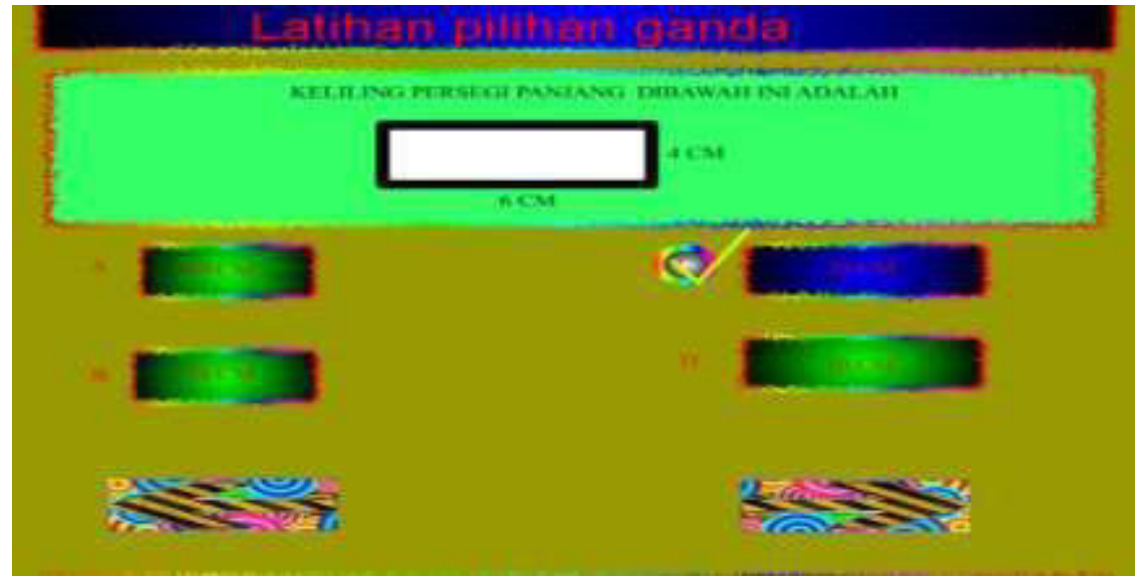

Gambar Pilhan ganda

Pada frame nilai user dapat mengulangi untuk menjawab soal dengan mengklik tombol ulang atau kembali ke menu pilihan latihan pilihan ganda. Jika pada menu latihan essay akan terdapat soal-soal latihan pada gambar dibawah ini dan jawaban benar atau salah bisa langsung dicek.

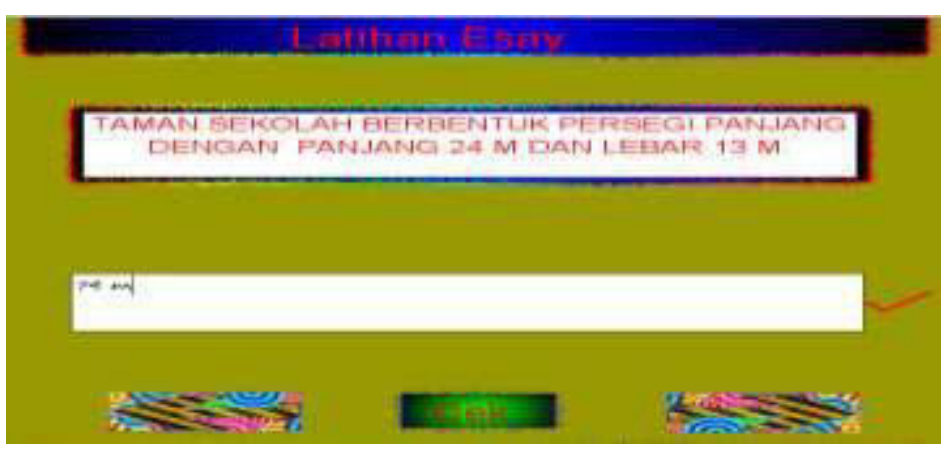

Gambar Latihan essay 


\section{Menu Pemecehan Masalah}

User dapat memilih tombol pemecahan masalah untuk menyelesaiakan soal latihan tematik SD kelas 3. Sedangkan tombol ke menu back berfungsi untuk kembali ke frame menu utama. Tombol pemecahan masalah dapat dilihat pada gambar 5 dibawah ini.

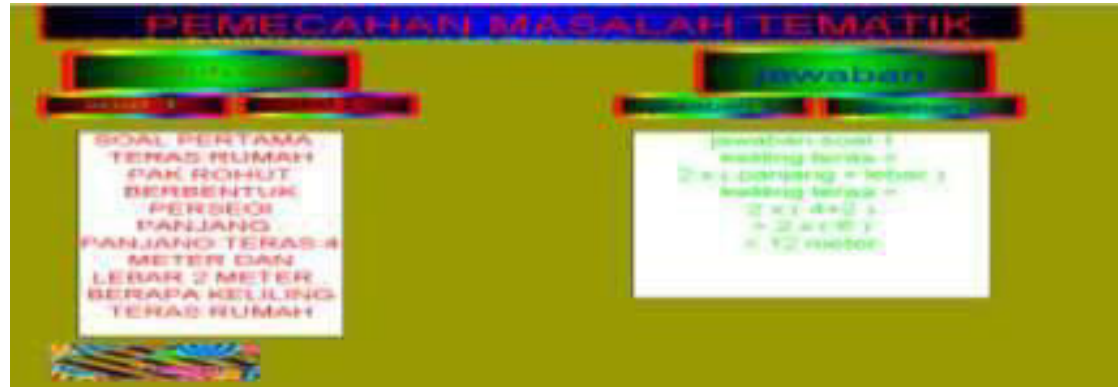

Gambar 5. Pemecahan masalah

Untuk dapat memilih tombol back untuk menutup frame pemecahan masalah dan kembali ke menu utama.

\section{Menu Video}

Pada frame ini akan menampilkan vidio pembelajaran tematik, pada frame vidio dapat dilihat pada gambar 6.Dibawah ini

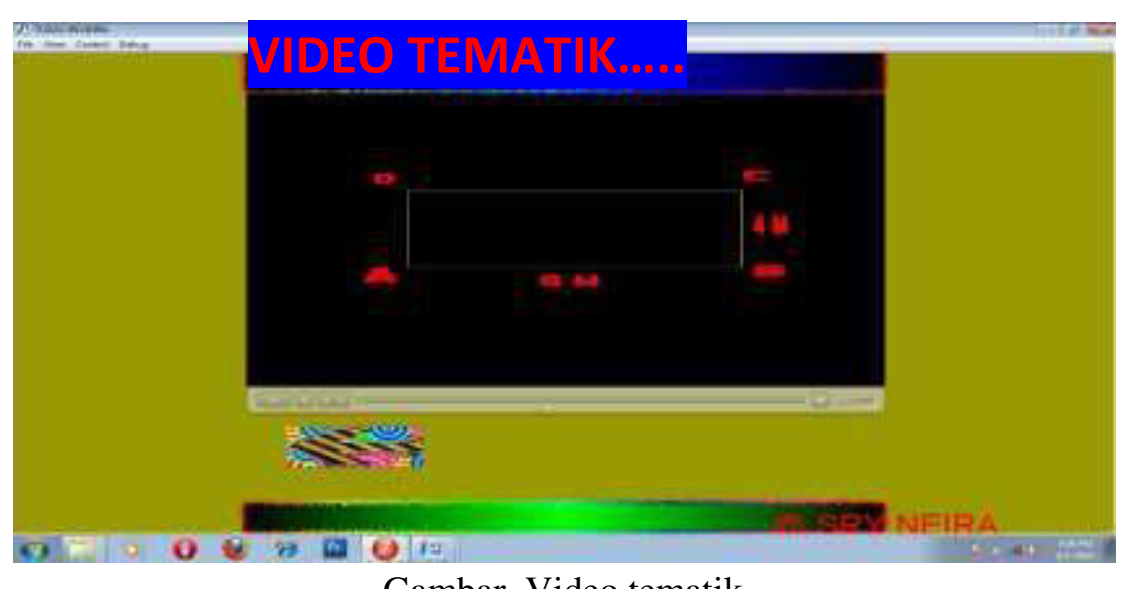

Gambar Video tematik

Untuk dapat memilih tombol back untuk menutup frame vidio dan kembali ke menu utama.

\section{Menu Permainan}

Pada frame ini akan menampilkan permainan tebak gambar pembelajaran tematik, pada frame permainan dapat dilihat pada gambar dibawah ini. 


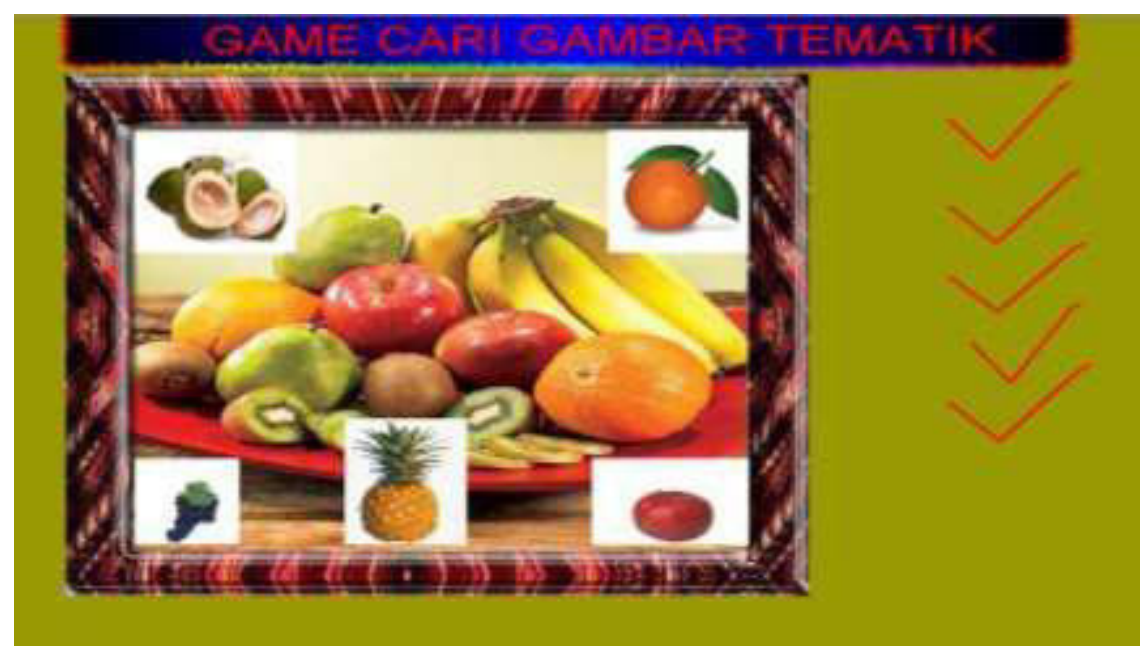

Gambar Permainan tebak gambar

Untuk dapat memilih tombol back untuk menutup frame permainan dan kembali ke menu utama.

\section{Tutorial}

Pada frame ini akan menampilkan tutorial gambar pembelajaran tematik, pada frame permainan dapat dilihat pada gambar dibawah ini.

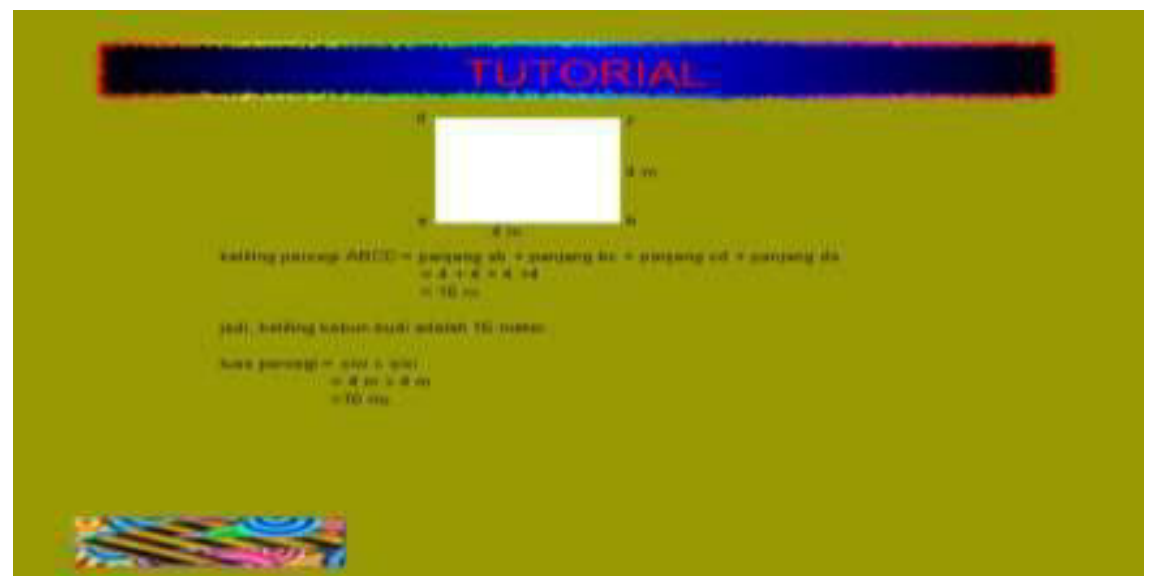

Gambar Tutorial

\section{SIMPULAN}

Adapun yang menjadi kesimpulan dari penulisan skripsi ini adalah sebagai berikut :

Penerapan metode CAI sebagai salah satu metode pembelajaran yang berbasis komputer mampu digunakan sebagai alat pendukung pencapaian buku panduan yang telah disusun, dan metode CAI melalui aplikasi media pembelajaran yang berbasis 
komputer dapat memberikan penekanan yang efektif dan memakai durasi waktu yang singkat.

Perancangan aplikasi pembelajaran tematik menggunakan Macromedia flash 8.0 yang menggunakan animasi dan suara, dibandingkan menggunakan buku panduan yang hanya membaca dan mendengar penjelasan dari guru.

\section{DAFTAR RUJUKAN}

Iru La, dkk.2012. Analisis Penerapan, Pendekatan, Metode, Strategi \& model-model pembelajaran.

Jogiyanto, 2005.Sistem Informasi.

Sugiarti, Yuni, 2012. Analisis \& Perancangan UML (Unified Modeling Language). Yogyakarta: Graha Ilmu.

Supardi, dkk. 2007. Mari Belajar Tematik Berkarakter Kebangsaan. Jateng: CV Usaha Makmur.

http://www.metodecomputeraidedinstruction(CAI), Hamalik 2003. Jurnal CAI USU. http://www.macromediaflash-8.html, 2013. Tampilan menu bar. 
